\title{
Structuring Industry ecology graduated education as a engineering professional discipline
}

\author{
Hongxu LI \\ School of metallurgical and ecological engineering , University of science and technology, Beijing \\ 100083, China \\ email: lihongxu@ustb.edu.cn
}

\begin{abstract}
Keywords: Graduate education; Industry ecology; Ecological engineer; Professional discipline; ecosystem
\end{abstract}

\begin{abstract}
According to the problem that the intelligence is not high of the soccer robot, using the mechanical theory as a guide, making some mechanical analyses and calculations on the pressure and transmutation states of chip kick mechanics, and conducting optimal design too, then making the structure of chip kick mechanics more and more rationalization. Experiments show that the new soccer robot controller features a quick response and high servo rigidity, and provide a kind of method for improving and perfecting the soccer robot control system, at the same time, filling the needs of producing. With the challenges and requirements of green ecological engineering development and industrial energy-saving emission reduction, the talent demand of industrial ecological aspects has increased rapidly in recent ten decades. However, no formal plan of study for industry ecology as a major has been disseminated, especially the lack of a graduated degree education of high specialist. This paper attempts to introduce the industrial ecological education concept, mode and experience carried on in engineering type universities, the plan of creating a program of study addressing the proficiencies a graduate student in industry ecology should have upon completion the degree based on the china educational system, to make the graduate of an industry ecology program as competitive on the labor market as students awarded traditional ecological engineering or environmental engineering degrees. Further, the specialization fields are suggested to complement the core of an industry ecology program, to enhance the education process and to give the student with a higher level of marketability degree.
\end{abstract}

\section{Introduction}

The world has entered the information era with industry civilization highly developed, in the manufacture and the use of products as well as people living process, it is experiencing a hitherto unknown energy and resource consumption. Especially in China, for over ten years, the economy has maintained a rapid growth of about GDP on average 10\%, in the energy and resources received serious limitation of today, maintaining the progress of economic development and human society, on the other hand to save energy resources and protecting the environment, the development of cleaner production is the only key and be imperative. while t. In all walks of life of production, the talent cultivation has focus on the education of the technic engineering and management specialized personnel, especially in the chemical industry, building materials, metallurgy, electric power and other large energy consumption industry field, but it is lack of industrial ecology specialist who have the knowledge and ideas guiding from the overall industry process view, considering the production, resource recycling, energy conversion as apart of the system of green production, and planning and designing the industry process and park using green design knowledge and system analysis methods[1,2]. So it very necessary for the education of training professional talents of industrial ecology, especially the master's and $\mathrm{PhD}$ at high levels to service in various industries. Based on our school's 10 years experience about ecological industry professional teaching, especially training of the postgraduate combined with metallurgical engineering major discipline, in the paper the education system construction and the training of graduate students of industrial ecology as a professional discipline will be discussed, and it will be 
creating a program of study addressing the proficiencies a graduate student in industry ecology should have upon completion of his/her degree study.

\section{The Plan of Subject Study}

Industrial ecology (IE) is an interdisciplinary framework for designing and operating industrial systems as living systems interdependent with natural systems. IE is the study of material and energy flows through industrial systems. The global industrial economy can be modeled as a network of industrial processes that extract resources from the Earth and transform those resources into commodities which can be bought and sold to meet the needs of humanity[3]. It seeks to balance environmental and economic performance within emerging understanding of local and global ecological constraints. Industrial ecologists are often concerned with the impacts that industrial activities have on the environment, with use of the planet's supply of natural resources, and with problems of waste disposal. Industrial ecology is a young but growing multidisciplinary field of research which combines aspects of engineering, economics, sociology, toxicology and the natural sciences, while the educated students always come from different other professional undergraduate study field with background engineering or environment[4,5].

In our university many students to be engaged in industry ecology study are before learning for metallurgy subjects, so it is need to establish a set of industrial ecological system of knowledge. Based on the china graduated education system, it is need Students to study special courses a semester or two, but not more than three semesters, the remaining about one to two year to do their thesis study combining with actual project. The plan shown in Fig.1 is developed to make the graduate of an industry program as competitive on the labor market as students awarded traditional environmental engineering degrees, and it aim to educate student who should be able to demonstrate are: (1) gaining access to existing knowledge, (2) displaying command of existing knowledge, (3) displaying the ability to draw out existing knowledge, (4) using existing knowledge to explore issues and (5) creating new knowledge, this is the graduate students especially $\mathrm{PhD}$ should have and the new subject of industry ecology as a pioneering subject provide a good chance to perform.

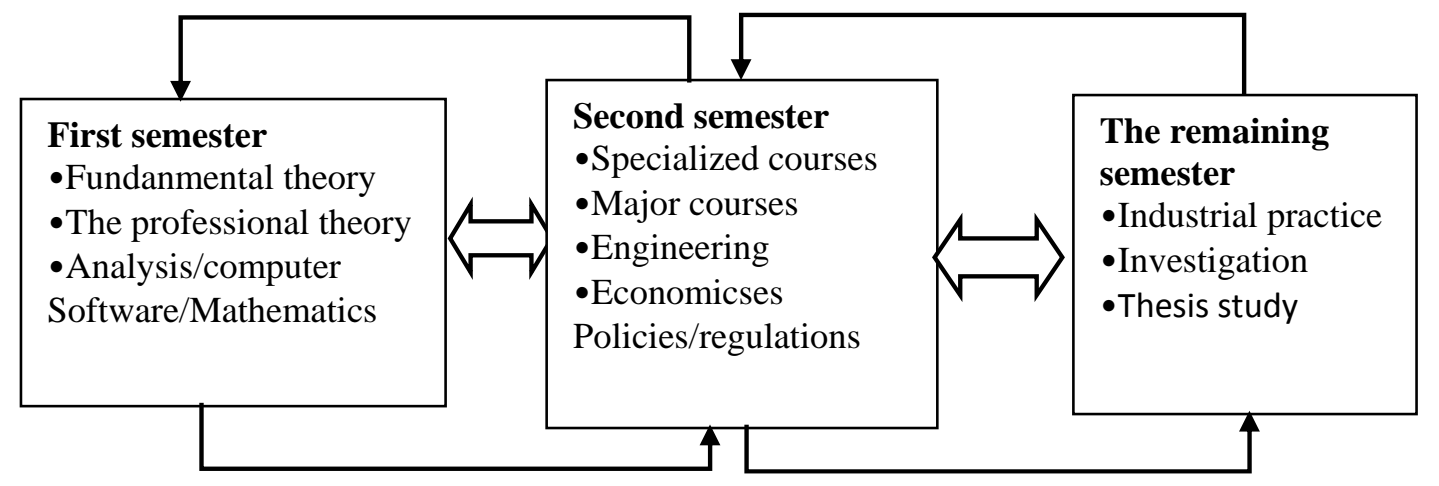

Fig.1 Industry ecology graduate plan of study

Due to the fact that industry ecology subject is inherently interdisciplinary in nature and industry process, knowledge of science and industry engineering requirement should be part of an ecological industry program. Industrial ecosystems are complex, dynamic, interconnected and some times unpredictable, where change is the rule, not the exception. To conserve and manage natural resources and energy consumption during industry manufacturing process, the human race must learn to work within the forces of change. In order to understand how new ideas and discoveries fit into the overall schemes of the environment and human life, change and how rapidly it occurs must be understood. Therefore, if students are going to be industry ecologists, with science and engineering knowledge needed, relative ecology principle theory and technic should be required to provide an understanding of the services an ecosystem provides, as well as its limitations. This 
requirement involves students in interdisciplinary subject system from the start of their graduate careers.

\section{The Curriculum Study}

Since 2003 our school set up ecology undergraduate professional, and At the same time, began to train graduate students in industrial ecological direction, including master's and doctoral. Graduated education plays a vital role in excellent engineers training as high professionals to enterprise, but they has less classroom learning time comparing with undergraduate students. What engineer do is what they were trained to do in their graduate programs. Therefore, a well formulated course of study is necessary.The curriculum presented in Table 1 is designed to train graduated students in industry ecology.

\begin{tabular}{|l|l|l|l|}
\hline $\begin{array}{l}\text { Fundanmental theory \& } \\
\text { Sotware/Mathematics }\end{array}$ & $\begin{array}{l}\text { Specialized basic } \\
\text { theory }\end{array}$ & $\begin{array}{l}\text { Professional } \\
\text { courses }\end{array}$ & Interdisciplinary course \\
\hline $\begin{array}{l}\text { Statistics } \\
\text { Probability theory } \\
\text { linear algebra }\end{array}$ & $\begin{array}{l}\text { Non-equilibrium } \\
\text { thermodynamics for } \\
\text { ecosystem }\end{array}$ & $\begin{array}{l}\text { Geosystem and } \\
\text { energy science }\end{array}$ & $\begin{array}{l}\text { Environmental economics } \\
\text { and ecological economics }\end{array}$ \\
\hline $\begin{array}{l}\text { Thermodynamics \& } \\
\text { Dynamics }\end{array}$ & $\begin{array}{l}\text { Nonlinear Dynamics for } \\
\text { process engineering }\end{array}$ & $\begin{array}{l}\text { Mass and energy } \\
\text { fluid analysis for } \\
\text { industry system }\end{array}$ & $\begin{array}{l}\text { Environmental police and } \\
\text { civilization }\end{array}$ \\
\hline Computer simulation & $\begin{array}{l}\text { Mass and energy } \\
\text { transport in } \\
\text { geochemical and } \\
\text { geosphere process }\end{array}$ & $\begin{array}{l}\text { Ecological effect } \\
\text { assesment (LCA) }\end{array}$ & $\begin{array}{l}\text { Environmental system } \\
\text { management }\end{array}$ \\
\hline General ecology & Industrial ecology & $\begin{array}{l}\text { Recycling system } \\
\text { for metallic system }\end{array}$ & $\begin{array}{l}\text { Metallurgy or chemical } \\
\text { engineering }\end{array}$ \\
\hline
\end{tabular}

Table 1 The curriculum study system

In all these curriculum there is a substantial nucleus of subject matter, which should be common to all industrial ecologists study. The core of a program of fundamental theory and research methods should taken by all graduate students, provides the fundamentals of that discipline. The goal of graduate education is to launch the student on a lifetime of self-education. Only the fundamentals sufficiently provide the groundwork for later self-education. The common core consists primarily of statistics probability theory, thermodynamics \& dynamics, computer simulation research methods and the general principles of ecology. The main specialized basic theory and methods of industry ecology theory courses are non-equilibrium thermodynamics for ecosystem and nonlinear dynamics for process engineering,these courses should be offered sequentially after first semesters study. the course material could be presented in a point-counter point format spanning the two semesters and progressing by complexity of topic. Guide the students using the classical thermodynamics and kinetics theory to analysis ecological system energy metabolism process. All of the common core courses will provide a graduate student in industry ecology study knowledge system an excellent foundation. Graduate programs should be directed toward enabling the student to acquire the fundamentals for which further building will be possible. In order to test the base knowledge of students, a series of comprehensive exams should be given for these core courses, like statistics probability theory, ecological thermodynamics, system dynamics, computer simulation research methods and the general principles of ecology. The exams rely largely on broad general questions requiring lengthy discussion, thus measuring a student's understanding of the fundamentals. Two other comprehensive examinations should be required to measure a student's understanding in the two specialized fields of his/her choosing.

Complementing the specialized basic theory courses, students should be well grounded in industrial process specific study from mass and energy fluid analysis aspects, in statistical and research methods such as LCA (life cycle assessment) and LCA (life cycle assessment). Due to the 
fact that industry ecology is inherently interdisciplinary, there are at least three disciplines cross, so the students should study specific knowledge of technical aspects of industrial production, like metallurgy process, chemical engineering process, materials producing, the resources used and the energy consumption, and soon on. Also natural resource management courses are needed, these included ecology, natural resources management, and environmental studies like ecosystem restoration, environmental engineering, ecosystems for waste treatment and materials reuse and recycling. Ecologists need to recognize the applied nature of their field to offer prescriptions, not just descriptions, for environmental problems.Engineers need to understand that biological and ecological sciences are fundamental to their tasks. A formal accreditation of ecological engineering should be developed in concert with existing engineering accreditations.Universities need to integrate ecology and engineering into rational and rigorous programs of ecological engineering. In order to understand how new ideas and discoveries fit into the overall schemes of the environment and human life, change and how rapidly it occurs must be understood and be accepted from green design, technical innovation, net production, new management of process, and obtaining the production profit, promoting economic development, so apart from ecology and industry technic theory and methods courses knowledge need to be acquired, students still more need learning knowledge of ecological economics, environmental police and management. Therefore, if students are going to be industrial ecologists and have market competition, the integrated curriculum courses should be required to provide an understanding of the services an industry ecosystem provides.

\section{Conclusion}

A formal graduated curriculum for industrial ecologists is necessary for the successful continuation of the discipline. To meet market demand the education plan and curriculum setting hope to help the industrial ecological specialist training, especially for postgraduate education. The University courses teaching of theoretical basis curriculum should be combined with major knowledge. Differ from conventional class, In response to the energy crisis, green production and sustainable development, defining the ecosystem and industry process as system and natural environment as as surroundings, it is necessary letting students to learn and think the basic thermodynamic laws from a more macro perspective of ecosystem, combining theory with Practice, enable students to better grasp and understand the process of industry manufacturing from energy and resources aspect, give innovation green design for products and manufacturing flowsheet.

\section{Acknowledgement}

The author gratefully acknowledge the financial support of the Teaching and education project (Improving the teaching methods of theory and practice for ecology thermodynamics course, 00008720, JG2012M13) of University of Science and Technology, Beijing.

\section{References}

[1] G.P.Hampson. Eco-logical education for the long emergency[J]. Futures, 2012 44(1) 71-80.

[2] M.J. Eckelman, R.J. Lifset, I. Yessios, K. Panko.Teaching industrial ecology and environmental management in Second Life [J]. Journal of Cleaner Production, 201119 1273-1278.

[3] J.M. Polimeni. Graduate education in ecological economics [J]. Ecological Economics, 200451 287-293.

[4] S.A.W. Diemont, T.J. Lawrence, T.A. Endreny. Envisioning ecological engineering education: An international survey of the educational and professional community [J]. Ecological Engineering, 201036 570-578.

[5] G.M. Hall, J. Howe. Sustainability of the chemical manufacturing industry-Towards a new paradigm? [J]. Education for Chemical Engineers, 20105 e100-e107. 